\title{
Remaking the City \\ Archaeological projects of political import in Jerusalem's Old City and in the village of Silwan
}

$\mathrm{T}$ he authors of this article are members of 'Emek Shaveh', an organization of archaeologists and community activists focusing on the role of archaeology in Israeli society and in the IsraeliPalestinian conflict. We view archaeology as a resource for building bridges and strengthening bonds between different peoples and cultures, and we see it as an important factor impacting the dynamics of the Israeli-Palestinian conflict. Our fundamental position is that an archaeological find should not and cannot be used to prove ownership by any one nation, ethnic group, or religion of a given place. We believe archaeology tells a complex story that is independent of tradition, religious or otherwise, and that by listening to this story and bringing it to the wider public we can promote values of tolerance and pluralism.

The historical AND Religious importance of the Old City of Jerusalem and its surroundings (the 'Historical Basin') is internationally recognized. ${ }^{*}$ As proposed by

* The article is based on Emek Shaveh's texts 'Archaeology in the shadow of the conflict' (2010), 'From Shiloah to Silwan' (2011), 'Jerusalem - Old City FAQ' (2012), 'From Silwan to the Temple Mount' (2012), 'Another future for
Jordan, the Old City and its Walls was nominated a World Heritage Site in Danger in 1982 (UNESCO World Heritage Center website). This status expresses the cultural value of the city's urban fabric and monuments, its extraordinary spiritual significance and its unique social composition, which is the result of many centuries of history and cultural development. In addition, Jerusalem is also at the heart of the Israeli-Palestinian political conflict. Jerusalem is contested ground, and the past has become hostage to this contest, with each side trying to tell a story that excludes the other. Much of the archaeological activity connected to the political conflict is taking place right outside the city walls, in an area which does not have UNESCO World Heritage status: the mound of ancient Jerusalem.

Today, this part of ancient Jerusalem is located in the village of Silwan, on a slope south of the Temple Mount/Haram el Sharif, outside of the Old City Walls. Silwan is home to approximately 40,000 Palestinians and since the 1990s, a few hundred Jewish settlers (Peace Now website). The Jewish settlement is promoted by an

antiquities' (2013) and 'Remaking the city' (2013). All are accessible as PDF-files on the Emek Shaveh website. organization called Elad, a Hebrew acronym for 'To the City of David' (Greenberg 1998: 8). The site is part of the 'Jerusalem Walls National Park' (Israel Antiquities Authority website), an area that was designated as a national park in 1974 and includes other land adjacent to the Old City. The national park as a whole is under the auspices of the Israel Nature and Parks Authority, but the specific site of ancient Jerusalem (City of David) in Silwan is managed by Elad (Lidman 2011). In recent years, the site has been visited by approximately 450,000 visitors per year, including tens of thousands of soldiers and university and high school students.

Ancient Jerusalem is a unique archaeological site of global importance for three main reasons: it is identified with the beginning of habitation in Jerusalem and was the capital of ancient Israelite kingdoms; it is located in a Palestinian village; and it is close to the Temple Mount/Haram al-Sharif - one of the most politically and religiously sensitive places in the Middle East. All of these characteristics present great challenges to any research undertaken in the area, both from an archaeological perspective and in terms of the social and political implications of the work.

Archaeological excavations are tied to the political conflict in Jerusalem from two distinct aspects. 
One is the appropriation of land to be excavated, which can be interpreted as a means of gaining control over a certain place or area. The second is the focus on the past, which can be seen as an instrument for appropriating the past to one particular group and its historical narrative. In this article we will discuss and exemplify these two aspects through the cases of the excavation at the Givati Parking Lot and the tunnel excavations which have been carried out since the mid-20oos in Silwan and in the Old City of Jerusalem.

\section{The Givati Parking Lot}

The Givati Parking Lot is an open area at the north end of the village of Silwan, across the street from the entrance to the Visitors Center of the City of David archeological park and at a distance of twenty metres from the walls of the Old City. Salvage excavations, funded by Elad and conducted under the auspices of the Israel Antiquities Authority (IAA), have taken place on the site 2003-5 and 2007-14. In the past, the lot was part of the open areas used by the residents of Silwan.

In June 2013, the Antiquities Authority began excavating the last unexcavated area in the Givati Parking Lot. The excavation completely consumes the parking lot that had been there, and ultimately, the entire parking lot area (some 5,000 $\mathrm{m}^{2}$ ) will be excavated. The goal of the archaeological excavation is to prepare the ground for the construction of the planned tourist centre known as the 'Kedem Compound'. According to an official decision of the District Committee for Planning and Building from June 2014 (Yashar 2014), the five-floor tourist centre is intended to occupy some $15,000 \mathrm{~m}^{2}$ and include commercial areas as well as a museum, parking lot, lecture halls and more. The archaeological remains will be displayed on a separate level in the building.

The archeological excavation served to prepare the area for future building development on three levels: 1) The deep excavation prepared the infrastructure and foundations for the future structure, so that once permits are attained from the planning and construction committees, construction will be able to begin immediately; 2) the public viewed the excavation as a scientific archeological excavation, and overlooked the fact that the dig was being used in order to advance the political goals of Elad and of certain government bodies. Thus, although the excavation in fact contributed to the creation of the infrastructure of Jewish settlement in Arab East Jerusalem, the Israeli governmental authorities and settlers were able to present their work as an exclusively scientific archeological excavation; 3) the archeological findings themselves not only

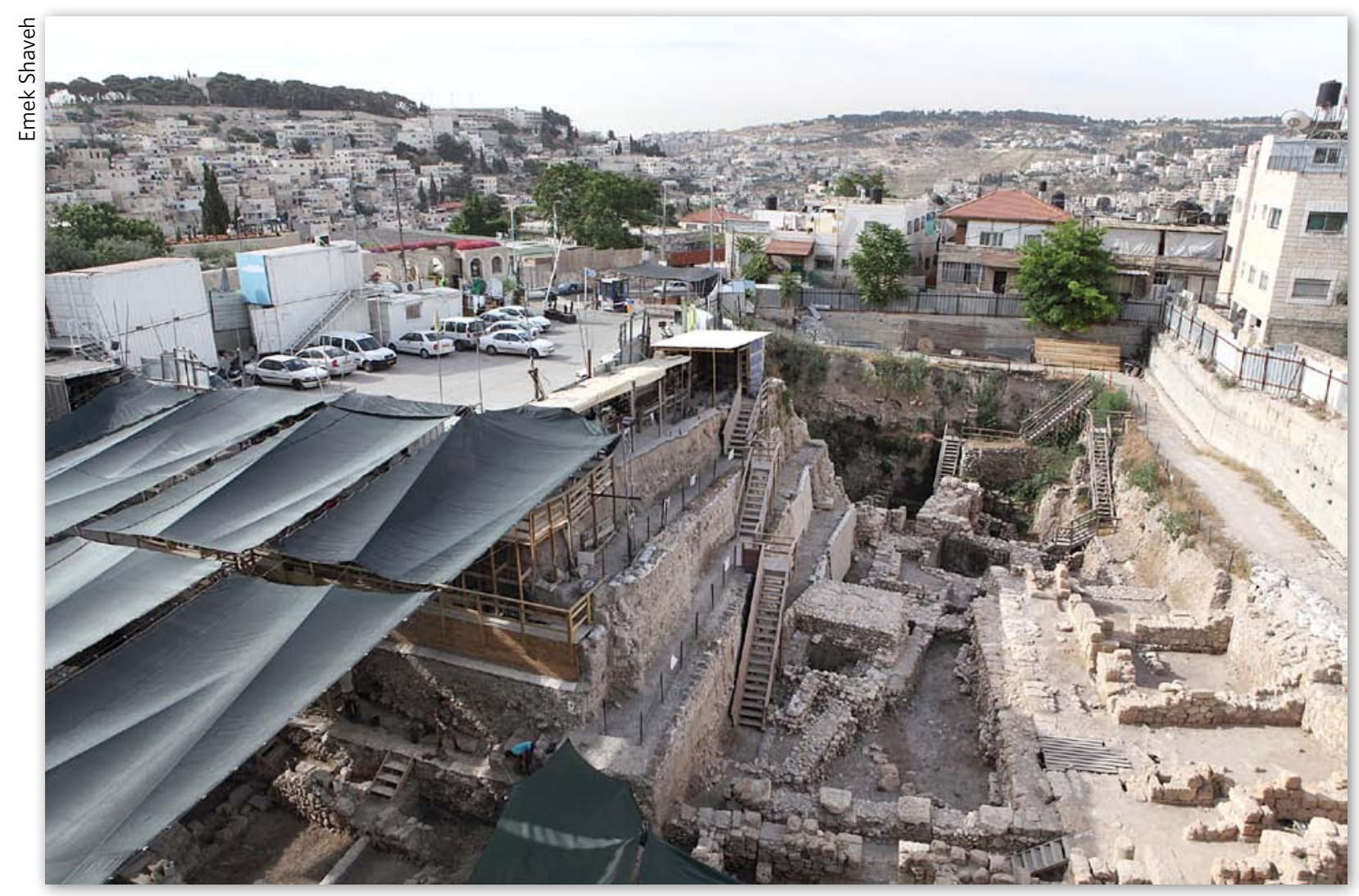

The Givati Parking Lot excavation. 


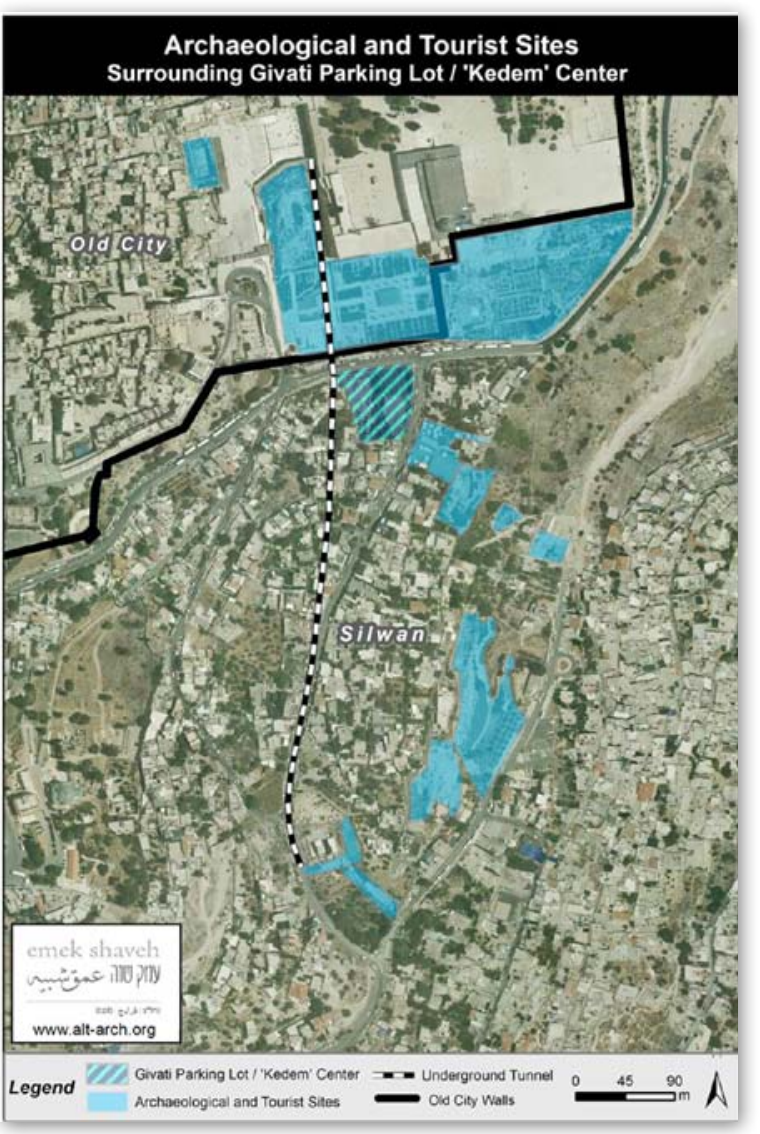

deflected potential opposition, but even aroused public sympathy and support for the excavation among the Israeli public. Over the years of the excavation, the media reported extraordinary findings in the excavations, from the greatest cache of gold coins from the Byzantine era (ABC Science 2008), to a Second Temple period structure, which some suggested was the palace of Queen Helena (Infolive.tv 2007). These reports and others created public interest in the archeological excavation and its findings.

According to the plan, visitors will use the centre as a starting point for a variety of routes in the village of Silwan and the Old City. The excavations at the Givati Parking Lot are already connected to the Ophel/Davidson Center excavations and to the Shiloah Pool through a system of tunnels. Two additional future projects relating to the Givati Parking Lot are the underground connection between it and the City of David Visitor Center, located across the street to the east, and an additional underground connection to the Ritual Bath Trail, located in the Ophel excavation area, immediately adjacent to the Old City Wall and ending just a few metres away from the Givati Parking Lot. The existing routes, together with the planned routes, will establish the Kedem Center as an alternative to today's main tourist entrance to the Old City, the Jaffa Gate. Although the archaeological excavations at the Givati Parking Lot uncovered finds from a broad range of historical periods (Ben-Ami and Tchehanovetz 2010), the compound is expected to have a clear biblical focus. According to a government decision in May 2012, the possibility of establishing a Bible museum called the 'Shrine of the Bible' in the Givati Parking Lot/Kedem Center in the village of

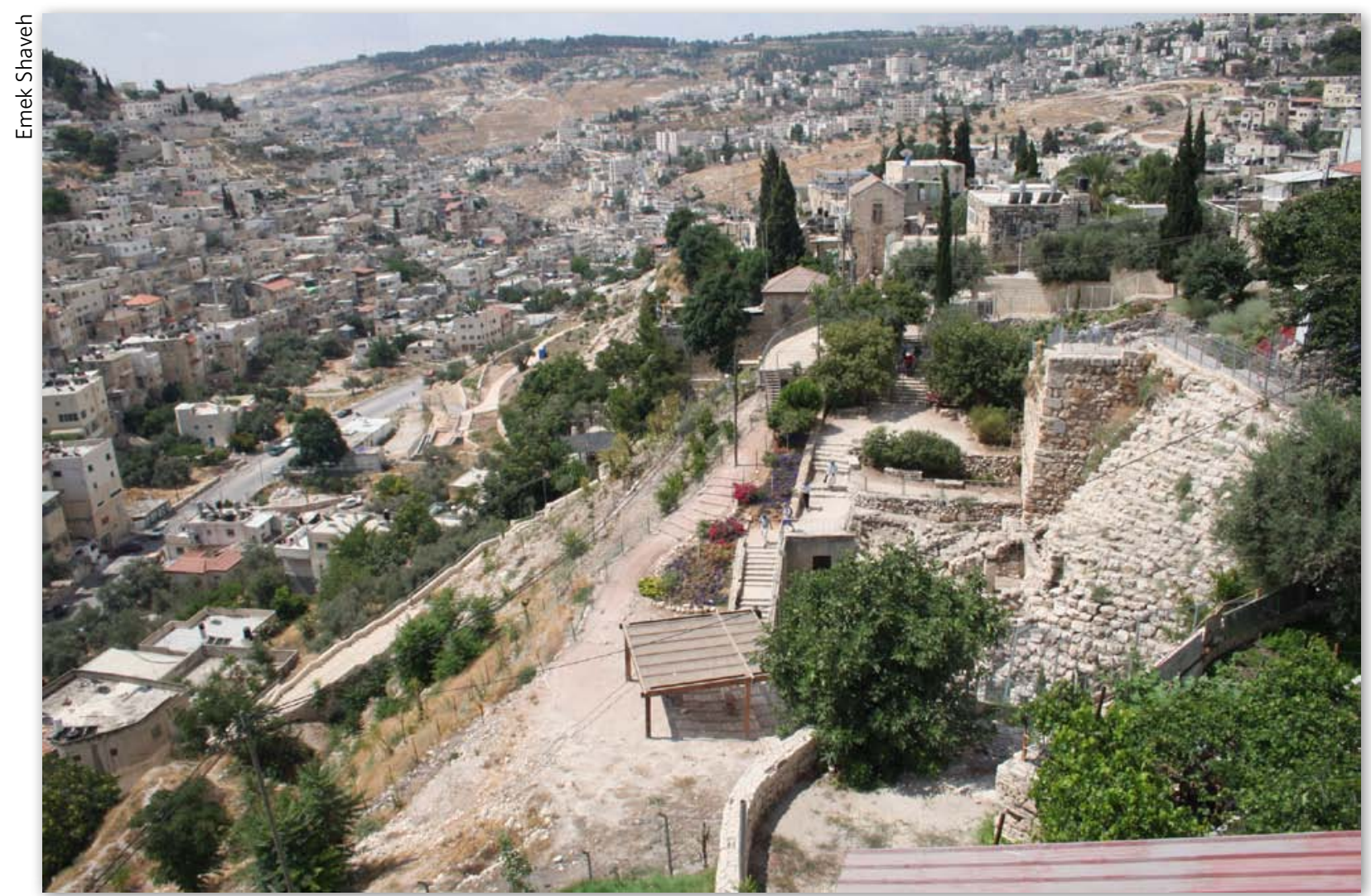

Archaeological excavations in the village of Silwan. 
Silwan is being considered (Protocol of government meeting 2012). The government's decision emphasizes the political importance of the archaeological projects in Silwan and constitutes an additional example of the close association between the plans of the settlers and the government.

The proposed building for the Givati Parking Lot overshadows the village of Silwan. The structure is anticipated to have a decisive influence on the landscape, on the way in which the walls of the Old City are perceived and enter the public consciousness, the character of the space between the village of Silwan and the Temple Mount/Haram alSharif, and the village of Silwan itself. Additionally, it is expected to have far-reaching implications for movement in the area, access to residents' homes, and the development of the Silwan village. Along with the City of David Visitor Center, it will create a single tourist zone under settler and Israeli governmental control.

\section{Jerusalem underground}

The intensive interest in underground tunnels and channels, whether ancient or contemporary, turns the clock back some 150 years. At that time, the first European archeologists in Jerusalem, aided by labourers from Jerusalem and its environs, dug deep into the heart of the Holy City in order to establish its ancient topography and the nature of the structures adjacent to the Temple Mount. First and foremost among them was Capt. Charles Warren, R.E. In order to avoid the prying eyes of the Ottoman authorities, Warren dug vertical shafts at some distance from the walls of the Temple Mount, and from there he continued to excavate in 'galleries' - horizontal tunnels dug along the ancient walls. Warren dug alongside the Western Wall, from the area of Robinson's Arch in the dir-

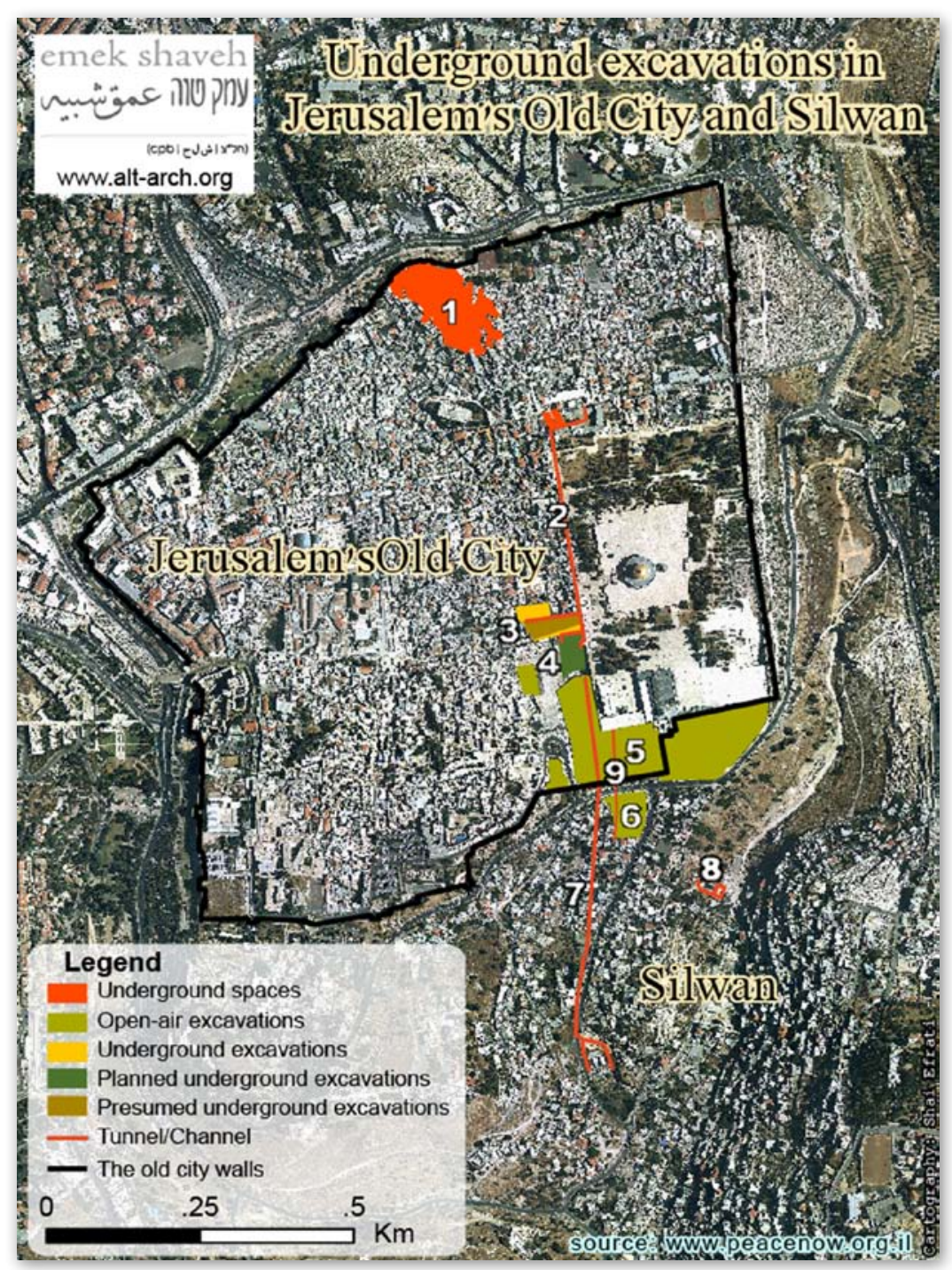

ection of Barclay's Gate (one of the gates of the Temple Mount/Haram al-Sharif) and north of there, at points that today constitute part of the network of 'Western Wall Tunnels. He exposed an ancient gate attributed to the temple complex of Herod (first century BCE), which led to the Temple Mount itself (Warren 1876). Warren's excavation project was also based on an 1862 map documenting the wells and water systems on the Temple Mount/Haram al-Sharif.

In addition to the excavations around the Temple Mount/Haram al-Sharif, Warren and his team dug in the adjacent village of Silwan, exposing important parts of a water system dating back to Bible- era Jerusalem. Here too, the excavations were conducted deep underground, far from the authorities' view. Among the things discovered there were shafts, tunnels, and channels - both naturally formed and man-made - that have become known as Warren's Shaft.

For as long as Ottoman rule lasted in Jerusalem, excavations continued in the shaft/gallery format. In 1894-7, the archeologists Fredrick Jones Bliss and Archibald Campbell Dickie dug a sprawling system of channels and tunnels around Mount Zion and the Siloam Pool/Birket al-Hamra. Between 1909 and 1911, an expedition led by Montagu Brownlow Parker renewed the investigation of 


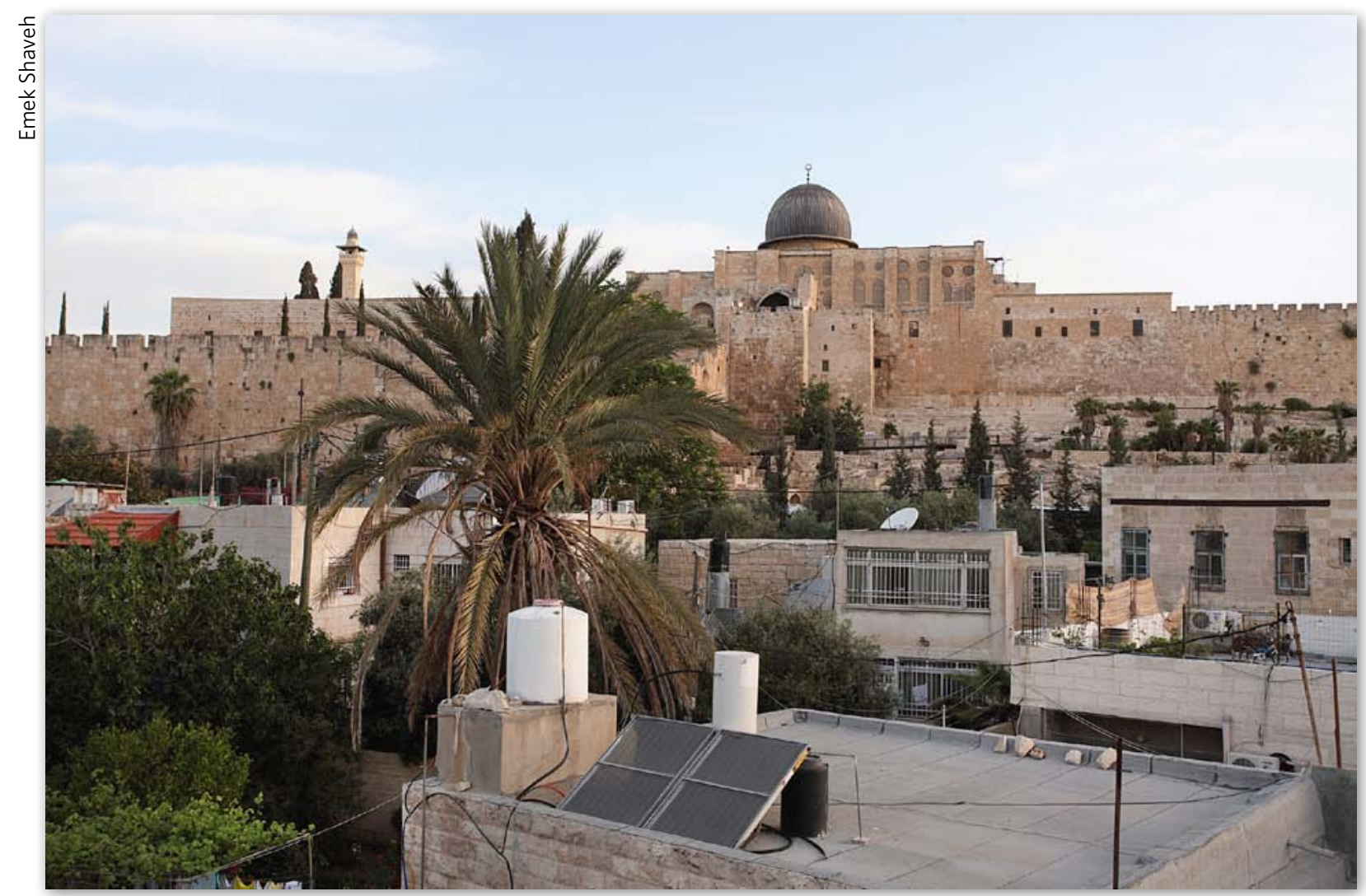

Silwan - view towards the Al-Aqsa Mosque.

the ancient waterworks of Jerusalem, hoping to find a subterranean passage from the Gihon Spring in Silwan to the heart of the Temple Mount, where, they hoped, they would discover the treasures of the Temple. Parker and his crew explored the Siloam Tunnel and Warren's Shaft and dug new galleries (Shalev-Khalifa 1999), but had to abandon the excavation following the disclosure of their attempt to bribe some waqf guards in order to dig under the Temple Mount itself.

This series of excavations, conducted behind the backs of the authorities, thus served to reinforce two central narratives regarding the archaeology of Jerusalem. The Western, scientific narrative that identified the 'real' Jerusalem beneath the surface, while viewing the present inhabitants of the city as degraded, benighted remnants of the past who obscured the importance and destiny of the Holy City; and the Muslim-Palestinian narrative, which viewed archaeology as a tool of Western imperialism aimed at undermining the Islamic presence in al-Quds (Jerusalem) and in the Haram al-Sharif.

The practice of digging horizontal tunnels underground fell into disuse, and has not been considered a legitimate scientific archaeological method for over a hundred years. It was replaced by the stratigraphic method, whereby digging is carried out vertically from the surface level down into the ground. This method affords a better understanding of the archaeological finds and the different layers, and prevents unnecessary damage and destruction.

In the Old City and the site of ancient Jerusalem, archaeologists are reverting back to the practice of digging tunnels. Currently there are several tunnels being dug in Silwan - some are dug continuously, some intermittently. The excavations are taking place underneath the village and in pursuit of specific archaeological finds, such as an ancient Roman street ascending from the Shiloah pool northwards, fortification digs towards the centre of the hill around the structure by the spring, and a dig at the centre of the Silwan village, undertaken for the purpose of cleaning out an ancient drainage system.

Digging tunnels in the name of archaeological research is less vulnerable to public criticism than an excavation which is not undertaken for research purposes, because the former is justified to the public as a meansyof studying and learning about the history of a site. Excavating tunnels in the site of ancient Jerusalem/Silwan places archaeological research at the cenere of the o-going territorial struggle in Jerusalem, and benefits the settlers in two ways: first, because the finds they may discover increase public interest and the number of visitors to the area under their control, and second, because it allows them to 
present the subterranean 'biblical' story to the public in a way that is completely unrelated to the aggressive and sometimes violent struggle for control currently taking place above ground.

The proliferation of underground spaces creates a physical link between the village of Silwan and the Old City, and among various areas in the Old City. The two central axes of the underground routes are the Givati Parking Lot and the Western Wall Plaza. The main tunnel excavated by the Antiquities Authority originates at the Shiloah Pool (Birket el-Hamrah) and passes nearby the Givati Parking Lot excavations, ending at the Old City.

Since 2007, the Antiquities Authority has been digging adjacent to the Pool of Shiloah/Birket alHamra along a length of street dated to the first century BCE, in other words, the Second Temple Period. The street was initially documentey during the nineteenth century by the scholars Bliss and Dickie (1898). The length of the stretch of road exposed is approximately forty meeres. Further down, at a level higher than that of the previous street, a covered drainage channel was exposed, taller than the height of the average man, and made out of stone. The channel passes beneath Wadi Hilweh Street in the village of Silwan along its entire length, and below the surrounding houses. It continues through the excavation area at the Kotel (the area of the Davidson Center) in the Old City, arriving at the Kotel Plaza (Hasson 2011). While excavation of the tunnel exposed an ancient street, further along there is an ancient sewage system that is higher than the street level, leading one to conclude that the two were built during different periods. The question of dating of the street remnants and the sewage system has still not been resolved. Despite this, the Antiquities
Authority and the City of David site present both the street segment and the sewage system as part of the street constructed during the Second Temple Period (the period of Roman Antiquity, i.e. between the first and second century BCE). The authority and the site administration even present this section of the street and the sewage system as the path that was tredden by pilgrims on their way to the Temple Plaza. (City of David 2012)

\section{Emek Shaveh's position}

The perspective informing Emek Shaveh's work is that the antiquities are cultural property that belong to the entire population, and in the case of Jerusalem, they are of exceptional interest and importance, extending beyond the interests of the two peoples in the conflict. Protection of the antiquities in the Historic Basin is of international interest, and their preservation should be treated as such. Consequently, our proposed plan is based on the following principles, which draw from the international conventions in the realm of the preservation of cultural heritage:

1. The historical city is an expression of the continuum of human cultures in time and space (New Life for Historic Cities 2013: 9). Various civilizations have made their mark on the city and continue to do so today. In a place such as Jerusalem, a complete presentation of the continuity of cultures is essential for generating recognition of the city's importance to various ethnic and religious groups.

2. An antiquities site does not exist in a vacuum, independent of its environment. It is essential to strive for a balance between the preservation and protection of cultural heritage, including antiquities sites, economic development (tourism), the needs of local residents and en- vironmental considerations. (New Life for Historic Cities 2013: 9)

3. Sustainable conservation is ineffective (and even impossible) without the agreement of the local residents. For the benefit of all parties, involvement of the local residents must be encouraged, as well as collaboration with them, to the extent possible (New Life for Historic Cities 2013: 9). This process can be facilitated by the transfer of credible information, providing residents with a response time, raising awareness of the importance of the preservation of cultural heritage, and educational and training programs (ICOMOS 2011).

The solution is to stop treating the past as an extension of faith and national mythology, and to reinstate the archaeological past as a universal human narrative; to conserve significant remains from every period in the city's history and to allow all those living in and visiting Jerusalem to discover the memories most meaningful to them.

ANNA VEEDER and JONATHAN MIZRACHI

\section{References}

ABC Science 2008. 'Byzantine coin hoard found under Jerusalem car park', ABC Science website, 24.12.2008, <http:// www.abc.net.au/news/stories/2008/12/24/2454211. htm? site $=$ science\&topic $=$ latest $>$ (accessed 6.7.2014)

Ben-Ami, Doron, and Yana Tchehanovetz, 2010. 'Jerusalem, Giv'ati parking lot: preliminary report', Hadashot Arkheologiyot. Excavations and Surveys in Israel 122, <http://www.hadashot-esi. org.il/report_detail_eng. aspx?id=1377\&mag_id=117> (accessed 7.10.2014)

Bliss, Frederick Jones, and Archibald Campbell Dickie, 1898. Excavations at Jerusalem (London)

City of David, 2012. 'Herodian 
road from Shiloah Pool to the Western Wall', City of David: Ancient Jerusalem, YouTube, 5.4.2012, <https://www.youtube. $\mathrm{com} /$ watch? $\mathrm{v}=\mathrm{Z}_{5} \mathrm{OaFxK} 14 \mathrm{yc}>$ (accessed 6.7.2014)

Emek Shaveh website. Emek Shaveh: Archeology in the Shadow of the Conflict website, <www.alt-arch. org $>$ (accessed 4.10.2014)

Greenberg, Joel, 1998. 'Settlers move into 4 houses in East Jerusalem, New York Times, 9.6.1998

Hasson, Nir, 2011. 'Digging completed on tunnel under Old City walls in East Jerusalem', Haaretz (English edition), 25.1.2011

ICOMOS, 2011. 'Valletta principles for the safeguarding and management of historic cities, towns and urban areas', International Council on Monuments and Sites website, <http://www.international.icomos. org/Paris2011/GA2011_CIVVIH_ text_EN_FR_final_20120110.pdf> (accessed 7.10.2014)

Infolive.tv, 2007. 'Massive complex dating from $70 \mathrm{AD}$ uncovered near Old City's dung gate', Infolive.tv, 6.12.2007, YouTube, <https://www. youtube.com/watch?v=Do-78yOvxLQ/> (accessed 6.7.2014)

Israel Antiquities Authority website. 'City of David (Jerusalem Walls) National Park', Israel Antiquities Authority website, <http://old. parks.org.il/BuildaGate5/general2/ data_card.php?Cat $=\sim 25 \sim \sim 25103$ 7795 Card 12 \&ru=\&SiteName $=$ parks $\&$ Clt $=\&$ Bur $=306221285>$ (accessed 6.7.2014)

Lidman, Melanie, 2011. 'El'ad can continue to operate City of David, court finds', Jerusalem Post, 26.11.2011

New Life for Historic Cities, 2013. New Life for Historic Cities: The Historic Urban Landscape Approach Explained (Paris), UNESCO World Heritage Center website, <http:// whc.unesco.org/uploads/news/ documents/news-1026-1.pdf> (accessed 6.7.2014)

Peace Now website. 'Ir David (Silwan)', Peace Now website, <http://peacenow.org.il/eng/content/ir-davidsilwan $>$ (accessed 6.7.2014)

Protocol of government meeting 2012. Protocol of government meeting
4654, 20.5.2012, Development of the City of Jerusalem, appendix 812, revised version, <http://www. pmo.gov.il/secretary/govdecisions/2012/pages/des4654.aspx> (accessed 7.10.2014)

Shalev-Khalifa, Nirit, 1999. 'Be'iqvot 'otsarot ha-miqdash. Sippura shel mishlakhat Parker she-khafra be'ir David ba-shanim 1909-1911' (In search of the temple treasures: the story of the Parker Expedition in the City of David 1909-11), Qadmoniot 2(116), pp. 126-33

UNESCO World Heritage Center website. 'Old City of Jerusalem and its Walls', UNESCO World Heritage Center website, <http://whc. unesco.org/en/list/148> (accessed 6.7.2014)

Warren, Charles, 1876. Underground Jerusalem (London)

Yashar, Ari, 2014. 'New City of David Tourism Center approved', Arutz 7, 4.4.2014, <http://www.israelnationalnews.com/News/News. aspx/179271\#.U7lHFNIW 3 A> (accessed 6.7.2014) 